\title{
Severity of Impact of Music Acoustics on Sustainability Performance of Buildings in Anambra State Nigeria
}

\author{
Peter Uchenna Okoye ${ }^{1, *}$, Chukwuemeka Ngwu $^{2}$, Kevin Chuks Okolie ${ }^{1}$, Christian Ifeanyi Ohaedeghasi ${ }^{1}$ \\ ${ }^{1}$ Department of Building, Nnamdi Azikiwe University, Nigeria \\ ${ }^{2}$ Department of Quantity Surveying, Nnamdi Azikiwe University, Nigeria
}

Received March 4, 2020; Revised April 3, 2020; Accepted April 19, 2020

Copyright $@ 2020$ by authors, all rights reserved. Authors agree that this article remains permanently open access under the terms of the Creative Commons Attribution License 4.0 International License

\begin{abstract}
This study examined the severity of the impacts of loud music sounds on the sustainability performance of buildings across three main cities in Anambra State Nigeria. Being a survey research, questionnaires were distributed to the users and occupiers of different classes of buildings in the study area. The survey results were analysed using means score index and severity index percent. The study found that loud music sounds severely affect the sustainability performance of buildings socially, environmentally, economically and technically with average means scores and severity index percent ranging from 3.73 to 4.64 and $54.89 \%$ to $100 \%$ respectively. The study further found that there was no significant difference in the severity of the impacts of loud music sounds on the sustainability performance of the buildings between the three main cities in Anambra State except for social sustainability which was due to differences in the social status of the three cities. Based on this, the study calls for change in the design and construction of buildings that would incorporate the provisions of National Building Code as regards to sound control in buildings. It suggested a review and reactivation of existing zoning laws and policies in the State, and a need to borrow a leaf from Lagos State Government by enacting a law against noise pollution. It further suggested promotion of acoustic practices that would improve sustainability performance of the buildings and reduce the consequential effects of music sounds in buildings.
\end{abstract}

Keywords Building Performance, Loud Music, Music Acoustics, Music Impact, Sustainability

\section{Introduction}

Scholarly interests in the relationships between music and nature have a long history, reaching back into the nineteenth century, but for reasons that perhaps reflect current global discourses of diversity and ecology, sustainability resonates widely and loudly in contemporary culture [1]. Sustainability and ecomusicology have brought up the concept of soundscape to awaken people to their natural acoustic surroundings in an increasingly noisy world. Music and all sounds are considered in vibrational terms as transferable energy, which impinges upon our body and our senses [2]. Acoustically, music is energy that pulsates through and across a medium; the structural interpretation and aesthetic conceptualisation of which occur when the sound has been processed, decoded, and interpreted in our nervous system [3].

Music industry no doubt has potential for economic and cultural sustainability. According to Wolcott [4], music has a critical role to play in the transition towards a culture of sustainability. Hawkes [5] suggests that cultural vitality which encompasses music is as essential to a healthy and sustainable society as social equity, environmental responsibility and economic viability. In terms of cultural ecology, music embraces a multilevel interconnection with organism, population, and community [6]. To this end, music becomes extremely cost-effective and powerful language that all cultures relate with, a direct and potent tool that sustain urban and rural community buildings as well as the healing process of individuals and communities [7]. Titon [8] sees music as bio-cultural resource that is renewable.

Economically, music industry in Nigeria, as in most parts of the world holds great potentials [7]. Available statistics shows that the record sales in Nigeria in 1981 was about 4.5 million; in 1986 it was 5.5 million; in 1991, 8.5 million and in 1995, 12 million records were sold nationwide [9]. Environmentally, music has been used to advance advocacy towards environmental sustainability [10-14].

\subsection{Statement of the Problem}

In the midst of a global warming crisis, we are currently 
living and running against the clock to counter the rapid depletion of natural resources in an increasingly technology-run world [15]. The tension added to the environment as a result of sounds emanating from the music soundscapes in our society today is a source of concern and a threat to the sustainability performance of our buildings. According to Janjua et al. [16], a sustainable building is the one that expresses a design philosophy that strives to enhance effective resource efficiency, and reduce negative impacts on human wellbeing and dignity, in a cost-effective manner.

Welch and Fremaux $[17,18]$ reveal that loud sound is present, in many activities, which are considered to be recreational, such as fitness canters, sports events, personal audio systems, live music events, bars, and night clubs, which all have high levels of sound. For example, Williams et al. [19] found that clubbers experience on average an equivalent continuous noise level of $98 \mathrm{dBA}$ Leq over an average attendance time of $5 \mathrm{~h}$ a week with an exposure of 12.2 $\mathrm{Pa}^{2}$ h. Similarly, an estimated 104 million individuals were found to had annual $\mathrm{L}_{\mathrm{EQ}}$ (24) levels > $70 \mathrm{dBA}$ (equivalent to a continuous average exposure level of $>70$ dBA over 24 hr) in 2013; and were at risk of noise-induced hearing loss with tens of millions more at risk of heart disease, and other noise-related health effects [20].

Although listening to soothing music no doubt reduces stress, blood pressure and post-operative trauma when compared to silence [21]. Working with louder music as well as listening to it over a long period of time may systematically lead to a permanent hearing damage or to a listening fatigue, which makes proper attention being impossible [22-24]. A more precarious situation is the acoustic quality of the buildings where we spend $90 \%$ of our time $[25,26]$. In this regard, high acoustic performances are unavoidable requirements which influence the quality and value of buildings [27].

Furthermore, music performance goes beyond the frontiers of mere entertainment activity but is geared more towards socio-cultural dimensions due to its ability to socialise, consolidate values and other utilitarian exigencies [28]. Titon [29] opines that ecomusicology should consider music's direct impact on the environment and flow of music and sound in the environment, rather than how musical compositions represent the environment as has shown by studies such as [30-33]. Unfortunately, the environmental movement in music is typically associated with the folk music genre, mostly because as an acoustic musical style, it lends itself well to conveying environmental messages through the lyrics [15].

The implications on the occupants and users of building as regards to building sustainability performance therefore, are many and varied owing to the makeup and nature of buildings in our cities. This development notwithstanding, has not attracted much scholarship interest. Most studies only centred on the effects of loud music sounds on the building users/occupants other than the building performance. It is against this backdrop that this study was aimed at examining the severity of the impacts of loud music sounds on the sustainability performance of buildings across the three main cities in Anambra State, Nigeria.

\section{Literature Review}

\subsection{Building Acoustics and Sustainability}

The goal of sustainable building concept is to create buildings that preserve the environment and conserve natural resources, as well as to provide a healthy environment for its occupants [34]. The acoustic performance of a building is one of the crucial factors which contribute to its quality [35]. Acoustic quality is also important in ensuring a healthy and workable working environment [36]. While a healthy environment is one that does not cause disease, promotes wellbeing and, in the case of places for work and learning, promotes productivity [34]; a good acoustic environment is absolutely essential to maintaining a high level of satisfaction and moral health among residents [37]. Therefore, considering the importance of health and wellbeing of persons inhabiting or working in a building, sound protection became an important indicator for social sustainability [38] and environmental sustainability aspects of buildings.

\subsection{Sources of Music Sounds}

As a sequence of waves of pressure that move, or propagate, through air or another medium, sound when propagated through a space, can be reflected (bounced back), refracted (bent), or attenuated (weakened) by the materials they come into contact with [26]. Environmental noise can be regarded as one of the agents of deterioration in people's quality of life in an urban environment [39]. According to Treasure [40], the acoustics of a space have a disproportionate impact on the wellbeing and productivity of its occupants.

Meanwhile, Oyati and Stephen [41] had identified mosques, churches, markets, schools, household appliance, events (wedding and birthday ceremonies) and loudspeakers among other sources as noise-generating centres in Auchi, Nigeria. Ganiyu and Adedeji [42] also observed noises from vehicular traffic, pedestrian traffic and religious buildings as the major sources of external noise, while those from generating sets, telephone/mobile phones, radio and television sets constitute the major sources of internal noise in Akure, Nigeria. Other sources of loud sounds include; cultural, sporting and leisure activities, music from clubs, concerts and festivals, indoor parties and music, etc. Ironically, most of the noises emanating from these centres are as a result of sounds from music or music related events. 


\subsection{Effect of Music Sounds}

Inasmuch as the characterisation of sound as noise is often subjective and it can vary across individuals [43], many other studies have demonstrated how sound environment can influence the peoples' behaviours positively and negatively [44-48]. Meng et al. [49] found that sound environment can affect human perception, and human perception can influence individual and crowd behaviour in both indoor and outdoor spaces. While Basner et al. [50] found that music sounds are usually continuous and if not controlled could have physical and mental health effects, psychological and non-auditory effects, and physiological and auditory effects; Treasure [40] revealed that the long-term exposure to excessive sound waves has been explicitly linked to the appearance or worsening of chronic conditions such as high blood pressure and heart disease. Challe [15] also stated that the high levels of noise interference can cause stress and hearing loss. As for Alves et al. [51], it can cause discomfort. Recent studies [52,53] have also shown that anthropogenic noise is potentially a threat to life on earth.

Even in the civilised cities of the world, music sound has been found to be causing acoustic pollutions [54,55]. Although the physical effects can be subjective to individuals depending on their personal and physical bearing [56,57], Association of Australian Acoustical Consultants [58] showed that sound had a knock-out effect on health and psychological bearing leading to decreased productivity. According to Reybrouck et al. [3] listening to loud music, seems to activate primitive mechanisms of experience, evoking to some extent an amodal kind of perception and surpassing to some extent boundaries between sensory modalities. This view is shared by Mujeebu [59] who found that acoustic comfort in a building has a crucial impact on the health, wellbeing, communication, and productivity of the occupants, and can be affected by factors such as the geometry and volume of a space, generation of sound within or outside the space, airborne noise transmission, impact noise, and the acoustic characteristics (absorption, transmission, and reflection of sound) of the interior surfaces.

A related study on the effects of exposure to building construction noise by $\mathrm{Ng}$ [60] revealed significant wing effects $(p<0.05)$ on frequency heard, distractibility, and several perceived behavioural effects, such as being awakened, difficulty with relaxation and studying-related activities, and interference with conversation and television-watching. It further showed that the effects were significantly more severe for residents closest to the construction site than those further away.

Other studies such as [15,34,35,39,40,42,61-64] attributed relaxation disturbance, impair task performance, irritation, interference with speech comprehension, sleep disturbance, falling asleep difficulty, deregulation of the physiological system, increase of cholesterol and triglycerides level in the blood, which subsequently leads to higher risk of heart attack, cardiovascular disease, cognitive impairment, tinnitus, annoyance, stress, attitude (negative emotion) and anxiety, nuisance, prolonged reaction time, lack of concentration, distraction and slowness of mental processing, increase in risk taking, increase of errors, and decrease in volume, speed and quantity to the effects of increased and irregular sounds of music. These impacts are mainly concerned with social and environmental performance of buildings. For Schiavi and Rossi [65], sound and architecture have mutual influence while Jablonska et al. [66] found that sound pressure induces vibration on the building.

Furthermore, a lot of research has shown that poor acoustic performance can have a negative impact on health, behaviour, and cognitive function, yet acoustics has been neglected in design and construction practices of buildings. Wilson [26] attributed this to partly due to a lack of awareness of how poor acoustic quality affects us and a total lack of understanding of acoustic as being an integral part of either aesthetics or functionality of a building.

A critical look at the buildings around us shows that most building envelopes have low sound attenuation due to ineffective insulation of the components of buildings. The condition is related to the non-consideration of acoustic criteria in our building designs and construction [67], unlike in the advanced countries [68]. Integrating acoustics into an established sustainable design and construction process is a balancing act to achieving a sustainable building, thus a more insight into the impact of different sources of acoustic problems (such as loud music) in building.

\section{Methodology}

This study was a survey research which made use of questionnaire administered to the occupants and users of buildings in the three cities of Awka, Onitsha and Nnewi in Anambra State. These cities are witnessing increased volume of musical events and activities due to their position in the State and the nature of activities going on in them. The researchers used selected sample from the population to discover the relative statistical distribution of selected sample of the population. The population for this study comprises all the users and occupants of buildings in the three cities.

The questionnaire was designed to elucidate the level of impact of loud music sounds on the sustainability performance of buildings in the three major cities of Anambra State, Nigeria. It was also designed to investigate the probability of occurrence and the severity of music sounds on certain sustainability criteria of buildings in the study area. The questionnaire consisted of two parts. Part 1 captured the respondents' demographic data (place of living, nature of user/occupant, type of building, age of respondents, location of building, and source of music sounds). Part 2 contained 29 items measuring the 
frequency of occurrence and severity of impacts of loud music on the sustainability performance of buildings using a 5-point Likert scale measurement. The respondents were asked to express their opinion and observations based on their perception on the impact of loud music sounds on the identified sustainability criteria of the selected buildings on a 5 -point scale where $1=$ least severe, $2=$ less severe, $3=$ severe, $4=$ more severe, $5=$ most severe.

According to the National Population Census figure, the population of Awka, Nnewi and Onitsha cities in 2006, were 143,660, 233,658 and 261,604 respectively [69,70-72]. Although there was observed disparity in the growth rate of population in these three cities; nationally, the population averagely grows at $2.83 \%$ growth rate [69]. This growth rate was recommended for use by the National Population Commission (NPC) for Anambra State and has used by the UN-Habitat and Anambra State Bureau of Statistics [70-73] for population projections in the state before now.

Therefore, in 2019, Awka, Nnewi and Onitsha populations would have been increased exponentially. Using Malthusian growth model in equation 1, the current population for the three cities could be computed. This model predicts an exponential increase in the population with time.

The Equation is given as:

$$
P_{n}=P_{0} e^{r t}
$$

Where $\mathrm{P}_{0}$ denotes the initial (base year) population;

$\mathrm{P}_{\mathrm{n}}$ denotes Population in the current year (required population);

$r$ denotes the growth rate $=2.83 \%(0.0283)$ (i.e. average population growth rate of Anambra State); and t denotes the time interval (years) $=13$ years.

From Equation 1, the population of Awka, Nnewi and Onitsha in 2019 would have been approximately 211,880, 337,566 and 377,940 respectively. Therefore, the total population of the study was 927,386. To determine the sample size, Israel [74] had suggested different ways including; census for a small population, sample size of a similar study, published table, and the use of formulas.

Hence, to determine the appropriate sample size for this study, Cochran's [75] sample size calculation procedure was used. The equation is appropriate when the population of the study is large [75]. Cochran's return sample size formula was first determined using Equation 2.

$$
n_{0}=\frac{(t)^{2} x(p)(q)}{(d)^{2}}
$$

Where $\mathrm{n}_{0}$ is the sample size, $\mathrm{t}=$ value for selected alpha level of .025 in each tail $=1.96$ (the alpha level of .05 indicates the level of risk the researcher is willing to take that true margin of error may exceed the acceptable margin of error), $(\mathrm{p})(\mathrm{q})=$ estimate of variance $=0.25$ (maximum possible proportion (0.5) x 1-maximum possible proportion (0.5) produces maximum possible sample size), $\mathrm{d}=$ acceptable margin of error for proportion being estimated $=0.05$ (error researcher is willing to except).

However, if the computed sample size is greater than $5 \%$ of the population ( $\mathrm{n}_{0}>5 \%$ population), the final and survey sample size would be calculated using Cochran's [75] correction formula in Equation 3. Otherwise $\mathrm{n}_{0}$ would be adopt as the final and survey sample size for the study.

$$
n_{1}=\frac{n_{0}}{1+\frac{n_{0}}{\text { population }}}
$$

From Equation 3, the sample size

$$
n_{0}=\frac{(1.96)^{2} x(0.5)(0.5)}{(0.05)^{2}} \approx 384
$$

Since $n_{0}(384)<5 \%$ of $927,386(46,369)$, the survey sample size $\left(\mathrm{n}_{1}\right)=\mathrm{n}_{0}=384$. However, the sample size was proportionately divided as follows for the three cities, Awka (88), Nnewi (140), and Onitsha (156).

The survey adopted a multi-stage sampling procedure in selecting the desired samples (respondents). Firstly, a proportional stratified sampling was used to subdivide the samples into 3 sub-groups. Stratified sampling technique was used in selecting the building in which the respondents occupy or use based on some specified criteria. Lastly, a simple random sampling technique was used in choosing the respondents within the selected buildings. Meanwhile, for one to be included in the survey, the person must be an adult, live, use or occupy a building susceptible to the effect of loud music sounds, and a maximum of three respondents were selected per building. In all, 30, 47 and 52 buildings making a total of 129 were selected from Awka, Nnewi, and Onitsha respectively.

Since not all occupants/users of the buildings were interested in participating in a survey, buildings which occupants/users agreed to be included were first identified for familiarisation and consent. The objectives of the study were clearly explained to the participants. This made it easier during the actual survey because the respondents were already aware of what was expected of them, and with the help of assistants, the desired numbers of respondents were obtained. Thus, questionnaires were administered to 384 occupants/users of buildings susceptible to the effect of loud music sounds across the three cities. All were retrieved, but 26 were found to be invalid and subsequently discarded while the remaining 358 (84 from Awka, 133 from Nnewi and 141 from Onitsha) representing about $93.23 \%$ were found to be adequate and suitable, and then were used for analysis.

To ensure reliability of the result, the margin of error was computed at $95 \%$ confidence interval (C.I) within which the result would be acceptable. Margin of error (ME) is given as:

$$
\begin{aligned}
& M E=\text { critical value } \mathrm{x} \text { standard error } \\
& \text { Standard error }=\text { standard deviation } / \sqrt{\mathrm{n}}
\end{aligned}
$$

Where, $\mathrm{n}=$ the sample; The Alpha level $(\alpha): \alpha=$ 1 -C.I $/ 100=0.05$. and C.I $=$ the confidence interval. 
0.975

The degrees of freedom $(\mathrm{df}): \mathrm{df}=\mathrm{n}-1=384-1=383$

In this case, it would be the t-statistic having 383 degrees of freedom and a cumulative probability equal to 0.975 . From the t-Distribution, the critical value is found to be 1.96. Thus, the result of this study is reliable and acceptable within $+/-5 \%$-point margin of error, and at the $95 \%$ confidence level. This is in line with Data Star [76] which suggested that an acceptable margin of error used by survey researchers falls between $4 \%$ and $8 \%$ at the $95 \%$ confidence level. Bartlett et al. [77] also recommended +/5\%-point margin of error for this kind of data.

The data generated through the questionnaire were descriptively and quantitatively analysis. The impacts of loud music sounds occurrence were calculated using Mean Score Index (MSI) and Severity Index Percent (SI\%) as shown in Equations 6 and 7 respectively.

$$
M S I=\frac{\sum_{j=1}^{5} J \times N j}{\sum_{j=1}^{5} N j}
$$

Where MSI = mean score index; $J=$ rating scale (integer value between 1 and 5 ), and $\mathrm{N}_{j}=$ number of the respondents selecting a rating equal to $j$.

$$
S I \%=\frac{\sum_{k=1}^{5} K \times N_{k}}{A \sum_{k=1}^{5} N_{k}} \times \frac{100}{1}
$$

Where SI = severity index; $K=$ rating scale (integer value between 1 and 5), $\mathrm{N}_{k}=$ number of the respondents selecting a rating equal to $k$, and $A=$ the highest weight (in this case, 5).

Thereafter, one-way ANOVA was used to establish the significance of the effect of loud music sounds on the sustainability performance of buildings in the study area. ANOVA or F-statistic can be calculated from Equation 8.

$$
F_{S T A T}=\frac{S_{B}^{2}}{S_{W}^{2}}
$$

I.e. the ratio of the variance between groups $\left(\mathrm{S}_{\mathrm{B}}{ }_{\mathrm{B}}\right)$ and the variance within group $\left(\mathrm{S}^{2}{ }_{\mathrm{w}}\right)$.

Where $S^{2}{ }_{B}=$ the sample variance between groups or means square between (MSB) which is a measure of variability of group means around the grand mean and is given in Equation 9 as:

$$
S_{B}^{2}=\frac{S S_{B}}{d f_{B}}
$$

Where $\mathrm{SS}_{\mathrm{B}}=$ sum of squares between groups and is given as:

$$
S S_{B}=\sum_{i=1}^{k} n_{i}\left(x_{i}-\bar{x}\right)^{2}
$$

Where $n_{\mathrm{i}}=$ the size of group (i); $x_{\mathrm{i}}=$ the mean of group (i); and $\bar{x}=$ the grand mean.

This statistic has degree of freedom $(d f)$

Where

$$
d f_{B}=K-1
$$

And $\mathrm{k}=$ the number of groups.

Likewise, $S^{2}{ }_{w}$ represents the sample variance within groups or mean square within (MSW) which quantifies the spread of values within groups. It is calculated as:

$$
S_{W}^{2}=\frac{S S_{W}}{d f_{W}}
$$

Where $\mathrm{SS}_{\mathrm{w}}=$ the sum of squares within and it's given as:

$$
S S_{W}=\sum_{i=1}^{k}\left(n_{i}-1\right) S_{i}{ }^{2}
$$

And degree of freedom (df) within is

$$
d f_{W}=N-K
$$

Where $S^{2}{ }_{i}=$ Variance of groups (i), $\mathrm{N}=$ the grand frequency, and $\mathrm{K}=$ the number of group.

Under this case, the null hypothesis will be tested and the test statistic has an $\mathrm{F}$ sampling distribution with $\mathrm{df}_{1}$ and $\mathrm{df}_{2}$ degrees of freedom and significant level $(\alpha)$ of $0.05(5 \%)$.

Decision: Reject $\mathbf{H}_{\mathbf{0}}$, if $\mathrm{F}$ stat calculated is greater than $F_{\text {critical }}$ at $\alpha=0.05$ and $\mathrm{df}_{1}$ and $\mathrm{df}_{2}$ otherwise accept $\mathbf{H}_{\mathbf{0}}$ and conclude.

\section{Results and Discussion}

Table 1 showed the general background information of the respondents. It revealed that the respondents were made up of $74.58 \%$ of male and $25.42 \%$ of female. Of this figure, $12.29 \%$ were aged between 18 -30 years, $29.34 \%$ were aged between $31-40$ years, $27.37 \%$ were aged between $41-50$ years, $19.27 \%$ were aged between $51-60$ years, and $11.73 \%$ were aged above 60 years. While $16.48 \%$ were single, $77.09 \%$ were married, $4.47 \%$ are widow/ widower, and $1.96 \%$ separated.

Table 1 also showed that majority (86.87\%) of the respondents had one form of formal education or the other and only about $13.13 \%$ did not had any form of formal education. This implied that the respondents were in good position to provide the necessary information for the study. Similarly, more than half (54.19\%) of the respondents were employed, $33.24 \%$ were self-employed and $12.57 \%$ were either unemployed or retired. This also shows that they can give good account of buildings in which the occupy or use. 
Table 1. Demographic information

\begin{tabular}{|c|c|}
\hline Variable & Responses (\%) \\
\hline $\begin{array}{c}\text { Sex Distribution } \\
\text { Male } \\
\text { Female }\end{array}$ & $\begin{array}{l}74.58 \\
25.42\end{array}$ \\
\hline $\begin{array}{l}\text { Age Distribution } \\
\text { 18-30 years } \\
31-40 \text { years } \\
41-50 \text { years } \\
51-60 \text { years } \\
\text { Above } 60 \text { years }\end{array}$ & $\begin{array}{l}12.29 \\
29.34 \\
27.37 \\
19.27 \\
11.73 \\
\end{array}$ \\
\hline $\begin{array}{c}\text { Marital Status } \\
\text { Single } \\
\text { Married } \\
\text { Widow/widower } \\
\text { Separated } \\
\end{array}$ & $\begin{array}{c}16.48 \\
77.09 \\
4.47 \\
1.96\end{array}$ \\
\hline $\begin{array}{c}\text { Educational Level } \\
\text { No Formal Education } \\
\text { Primary } \\
\text { Secondary } \\
\text { Tertiary } \\
\end{array}$ & $\begin{array}{l}13.13 \\
20.67 \\
35.47 \\
30.73 \\
\end{array}$ \\
\hline $\begin{array}{c}\text { Employment status } \\
\text { Employed } \\
\text { Self employed } \\
\text { Unemployed/ Retired }\end{array}$ & $\begin{array}{l}54.19 \\
33.24 \\
12.57 \\
\end{array}$ \\
\hline $\begin{array}{c}\text { Building use } \\
\text { Business/commercial } \\
\text { Residential } \\
\text { Recreational } \\
\text { Office } \\
\text { Mixed use }\end{array}$ & $\begin{array}{c}20.39 \\
37.71 \\
4.19 \\
15.08 \\
22.63\end{array}$ \\
\hline $\begin{array}{c}\text { Period of occupancy/use } \\
\text { Less than } 1 \text { year } \\
1-5 \text { years } \\
6-10 \text { years } \\
11-20 \text { years } \\
\text { Above } 20 \text { years }\end{array}$ & \begin{tabular}{c|c}
1.68 \\
13.13 \\
37.15 \\
31.28 \\
16.76
\end{tabular} \\
\hline
\end{tabular}

In terms of the type of building being use/occupied by the respondents, $20.39 \%$ were business/commercial building, $37.71 \%$ were residential building, $4.19 \%$ were recreational building, $15.08 \%$ were office building, while about $22.63 \%$ were of mixed use. For the period of time the respondents have either used or occupied the building, $1.68 \%$ indicated less than 1 year, $13.13 \% 1-5$ years, $37.15 \%$ 6-10 years, $31.28 \% 11-20$ years and $16.76 \%$ said that they have used or occupied the buildings for more than 20 years. This also shows that the respondents could be able to give information on what happens to the buildings and the building performance having used or occupied the buildings for a substantial number of years.

Table 2 showed the result of the impact of loud music sounds on the sustainability performance of building from Awka City. It revealed that the sustainability performance of building could be affected by the loud music sounds in four areas: environmental, social, economic and technical. In terms of environmental sustainability, the result showed that release of environmental pollution $(\mathrm{MSI}=4.87$; SI\% = 97.38) and decrease in indoor environmental quality (MSI $=4.85 ; \mathrm{SI} \%=96.91$ ) were the top severe impact loud music sounds have on buildings.

Similarly, increase annoyance, anger and frustration in users/occupants $(\mathrm{MSI}=5.00 ; \mathrm{SI} \%=100.00)$, increase eardrum damage or hearing difficulties (MSI $=5.00$; SI $\%=$ 100.00 ) and decrease users' comfort and satisfaction (MSI $=4.96 ; \mathrm{SI} \%=99.29$ ) were the three top social impact exerted on the building by the loud music sounds. Economically, decrease housing price and value (MSI = 4.56; $\mathrm{SI} \%=91.19)$ and increase medical cost to users/occupants $(\mathrm{MSI}=4.33$; $\mathrm{SI} \%=86.97)$ were the top two economic impact of loud music sounds on buildings. In terms of technical impacts, increase sound induced vibrations in building (MSI $=5.00 ; \mathrm{SI} \%=100.00)$ and deteriorate building fabrics $(\mathrm{MSI}=4.40 ; \mathrm{SI} \%=88.10$ ) came top respectively.

Table 2 further revealed that social sustainability performance of building was mostly affected by loud music sounds with average mean score index of 4.64, followed by the economic sustainability (4.21), environmental sustainability (4.14), and lastly technical sustainability (3.87) respectively. The high average means scores imply that loud music sounds severely impact the overall sustainability performance of buildings in Awka city. This can be attested from the results of the severity impacts percent of the individual variables. 
Table 2. Analysis of the impact of loud music sounds on the sustainability performance of building (Responses from Awka)

\begin{tabular}{|c|c|c|c|c|c|c|c|c|c|}
\hline SN & Variable & 1 & 2 & 3 & 4 & 5 & $\begin{array}{l}\text { Mean } \\
\text { Score } \\
\text { Index } \\
\end{array}$ & $\begin{array}{l}\text { Severity } \\
\text { Index (\%) }\end{array}$ & $\begin{array}{c}\text { Group } \\
\text { mean/ Std } \\
\text { D. }\end{array}$ \\
\hline \multicolumn{10}{|c|}{ Environmental Sustainability } \\
\hline 1 & Increase energy consumption in building & & & 13 & 58 & 13 & 4.00 & 80.00 & \multirow{6}{*}{$\begin{array}{l}4.14 \\
0.90\end{array}$} \\
\hline 2 & Release volatile organic compounds (VOC) & & 11 & 39 & 29 & 5 & 3.33 & 66.66 & \\
\hline 3 & Release toxic air contaminants & & & 8 & 33 & 42 & 4.36 & 87.14 & \\
\hline 4 & Decrease indoor environmental quality & & & & 13 & 71 & 4.85 & 96.91 & \\
\hline 5 & Release environmental pollution & & & & 11 & 73 & 4.87 & 97.38 & \\
\hline 6 & Disrupt biodiversity and natural habitats & & 13 & 32 & 29 & 10 & 3.43 & 68.57 & \\
\hline \multicolumn{10}{|c|}{ Social Sustainability } \\
\hline 1 & Threat to security of building & & & 27 & 45 & 12 & 3.82 & 76.43 & \multirow{14}{*}{$\begin{array}{l}4.64 \\
0.58\end{array}$} \\
\hline 2 & $\begin{array}{l}\text { Threat to health and wellbeing of users and } \\
\text { occupants }\end{array}$ & & & & 5 & 79 & 4.94 & 98.81 & \\
\hline 3 & Increase workplace accidents and injuries & & & & 64 & 20 & 4.24 & 84.76 & \\
\hline 4 & Decrease users' comfort and satisfaction & & & & 3 & 81 & 4.96 & 99.29 & \\
\hline 5 & Sleep disturbance & & & & 12 & 72 & 4.86 & 97.14 & \\
\hline 6 & Create tension or anxiety within the building & & & & 9 & 75 & 4.89 & 97.86 & \\
\hline 7 & Psychological damage to users/occupants & & & & 19 & 65 & 4.77 & 95.55 & \\
\hline 8 & $\begin{array}{l}\text { Increase annoyance, anger and frustration in } \\
\text { users/occupants }\end{array}$ & & & & & 84 & 5.00 & 100.00 & \\
\hline 9 & $\begin{array}{c}\text { Increase blood pressure or stress levels in } \\
\text { users/occupants }\end{array}$ & & & & 10 & 74 & 4.88 & 97.62 & \\
\hline 10 & $\begin{array}{c}\text { Increase rate of sickness or absenteeism in } \\
\text { users/occupants }\end{array}$ & & & 13 & 38 & 33 & 4.24 & 84.76 & \\
\hline 11 & $\begin{array}{c}\text { Decrease performance and productivity of } \\
\text { users/occupants }\end{array}$ & & & 22 & 41 & 21 & 3.99 & 79.76 & \\
\hline 12 & $\begin{array}{l}\text { Increase Eardrum damage or hearing } \\
\text { difficulties }\end{array}$ & & & & & 84 & 5.00 & 100.00 & \\
\hline 13 & Speech interference & & & & 21 & 63 & 4.75 & 95.00 & \\
\hline 14 & Reduce quality of life & & & & 28 & 56 & 4.67 & 93.33 & \\
\hline \multicolumn{10}{|c|}{ Economic Sustainability } \\
\hline 1 & Decrease housing price and value & & & & 37 & 47 & 4.56 & 91.19 & \multirow{4}{*}{$\begin{array}{l}4.21 \\
0.84\end{array}$} \\
\hline 2 & Increase maintenance cost of building & & 10 & 15 & 35 & 24 & 3.87 & 77.38 & \\
\hline 3 & Increase medical cost to users/occupants & & 2 & 10 & 30 & 42 & 4.33 & 86.67 & \\
\hline 4 & Increase insurance premium & & 3 & 21 & 27 & 33 & 4.07 & 81.43 & \\
\hline \multicolumn{10}{|c|}{ Technical Sustainability } \\
\hline 1 & Deteriorate building fabrics & & & 14 & 22 & 48 & 4.40 & 88.10 & \multirow{5}{*}{$\begin{array}{l}3.87 \\
1.04\end{array}$} \\
\hline 2 & $\begin{array}{l}\text { Increase sound induced Vibrations in } \\
\text { building }\end{array}$ & & & & & 84 & 5.00 & 100.00 & \\
\hline 3 & $\begin{array}{l}\text { Decrease structural stability and durability } \\
\text { of building }\end{array}$ & & & 64 & 15 & 5 & 3.30 & 65.95 & \\
\hline 4 & $\begin{array}{l}\text { Reduce functionality and serviceability of } \\
\text { building }\end{array}$ & & 6 & 55 & 19 & 4 & 3.25 & 65.00 & \\
\hline 5 & Induce reverberation and reflection & & 13 & 30 & 17 & 20 & 3.38 & 67.62 & \\
\hline
\end{tabular}


Table 3. Analysis of the impact of loud music sounds on the sustainability performance of building (Responses from Nnewi)

\begin{tabular}{|c|c|c|c|c|c|c|c|c|c|}
\hline SN & Variable & 1 & 2 & 3 & 4 & 5 & $\begin{array}{l}\text { Mean } \\
\text { Score } \\
\text { Index }\end{array}$ & $\begin{array}{l}\text { Severity } \\
\text { Index (\%) }\end{array}$ & $\begin{array}{l}\text { Group } \\
\text { mean/ } \\
\text { Std D. }\end{array}$ \\
\hline \multicolumn{10}{|c|}{ Environmental Sustainability } \\
\hline 1 & Increase energy consumption in building & 9 & 10 & 32 & 64 & 18 & 3.54 & 70.83 & \multirow{6}{*}{$\begin{array}{l}3.80 \\
1.11\end{array}$} \\
\hline 2 & Release volatile organic compounds (VOC) & 17 & 34 & 55 & 20 & 7 & 2.74 & 54.89 & \\
\hline 3 & Release toxic air contaminants & & 10 & 19 & 48 & 56 & 4.13 & 82.56 & \\
\hline 4 & Decrease indoor environmental quality & & & & 36 & 97 & 4.73 & 94.59 & \\
\hline 5 & Release environmental pollution & & & 14 & 32 & 87 & 4.55 & 90.98 & \\
\hline 6 & Disrupt biodiversity and natural habitats & 12 & 18 & 54 & 39 & 10 & 3.13 & 62.56 & \\
\hline \multicolumn{10}{|c|}{ Social Sustainability } \\
\hline 1 & Threat to security of building & 7 & 22 & 42 & 50 & 12 & 3.29 & 65.71 & \multirow{14}{*}{$\begin{array}{l}4.48 \\
0.57\end{array}$} \\
\hline 2 & $\begin{array}{l}\text { Threat to health and wellbeing of users and } \\
\text { occupants }\end{array}$ & & & 4 & 18 & 111 & 4.80 & 96.09 & \\
\hline 3 & Increase workplace accidents and injuries & & & 29 & 59 & 45 & 4.12 & 82.41 & \\
\hline 4 & Decrease users' comfort and satisfaction & & & 10 & 33 & 90 & 4.60 & 92.03 & \\
\hline 5 & Sleep disturbance & & & 6 & 20 & 107 & 4.67 & 93.38 & \\
\hline 6 & $\begin{array}{c}\text { Create tension or anxiety within the } \\
\text { building }\end{array}$ & & 10 & 21 & 36 & 66 & 4.19 & 83.76 & \\
\hline 7 & Psychological damage to users/occupants & & & 13 & 33 & 87 & 4.56 & 91.13 & \\
\hline 8 & $\begin{array}{c}\text { Increase annoyance, anger and frustration in } \\
\text { users/occupants }\end{array}$ & & & & 19 & 114 & 4.86 & 97.14 & \\
\hline 9 & $\begin{array}{c}\text { Increase blood pressure or stress levels in } \\
\text { users/occupants }\end{array}$ & & 4 & 17 & 22 & 90 & 4.49 & 89.77 & \\
\hline 10 & $\begin{array}{c}\text { Increase rate of sickness or absenteeism in } \\
\text { users/occupants }\end{array}$ & & & 41 & 39 & 53 & 4.09 & 81.80 & \\
\hline 11 & $\begin{array}{c}\text { Decrease performance and productivity of } \\
\text { users/occupants }\end{array}$ & & & 15 & 65 & 53 & 4.29 & 85.71 & \\
\hline 12 & $\begin{array}{l}\text { Increase Eardrum damage or hearing } \\
\text { difficulties }\end{array}$ & & & 12 & 33 & 88 & 4.57 & 91.43 & \\
\hline 13 & Speech interference & & 8 & 10 & 27 & 94 & 4.69 & 93.83 & \\
\hline 14 & Reduce quality of life & & & 28 & 34 & 71 & 4.32 & 86.47 & \\
\hline \multicolumn{10}{|c|}{ Economic Sustainability } \\
\hline 1 & Decrease housing price and value & & 19 & 22 & 30 & 62 & 4.03 & 80.30 & \multirow{4}{*}{$\begin{array}{l}4.01 \\
1.00\end{array}$} \\
\hline 2 & Increase maintenance cost of building & & 22 & 14 & 53 & 44 & 3.89 & 77.89 & \\
\hline 3 & Increase medical cost to users/occupants & & & 28 & 57 & 48 & 4.15 & 83.01 & \\
\hline 4 & Increase insurance premium & & 21 & 14 & 44 & 54 & 3.98 & 79.70 & \\
\hline \multicolumn{10}{|c|}{ Technical Sustainability } \\
\hline 1 & Deteriorate building fabrics & & 16 & 14 & 22 & 81 & 4.26 & 85.26 & \multirow{5}{*}{$\begin{array}{l}3.93 \\
1.03\end{array}$} \\
\hline 2 & $\begin{array}{l}\text { Increase sound induced Vibrations in } \\
\text { building }\end{array}$ & & & 5 & 52 & 76 & 4.53 & 90.68 & \\
\hline 3 & $\begin{array}{l}\text { Decrease structural stability and durability } \\
\text { of building }\end{array}$ & & & 58 & 40 & 35 & 3.83 & 76.54 & \\
\hline 4 & $\begin{array}{l}\text { Reduce functionality and serviceability of } \\
\text { building }\end{array}$ & 8 & 26 & 42 & 30 & 27 & 3.32 & 66.32 & \\
\hline 5 & Induce reverberation and reflection & & 12 & 50 & 38 & 33 & 3.69 & 73.83 & \\
\hline
\end{tabular}

Table 3 showed the result of the impact of loud music sounds on the sustainability performance of building from Nnewi City. The results revealed that the top three environmental impacts of loud music sounds on buildings were similar to that in Table 2 but with slight difference. Whereas decrease in indoor environmental quality has (MSI $=4.73$; SI\% $=94.59)$, release of environmental pollution has $(\mathrm{MSI}=4.55$; SI\% $=90.98)$, and release toxic air contaminants has $(\mathrm{MSI}=4.13$; $\mathrm{SI} \%=82.56)$.

However, increase annoyance, anger and frustration in users/occupants with $(\mathrm{MSI}=4.86$; SI\% $=97.14)$, and threat to health and wellbeing of users and occupants with (MSI = 4.80; SI\% $=96.09$ ) were the two top social impact loud music sounds have on buildings.

In terms of economic sustainability, increase medical cost to users/occupants (MSI $=4.15 ; \mathrm{SI} \%=83.01)$ and decrease housing price and value $(\mathrm{MSI}=4.03$; $\mathrm{SI} \%=80.30$ ) were the top two impact of loud music sounds on buildings.

Technically, increase sound induced vibrations in building (MSI $=4.53$; SI\% $=90.68$ ), deteriorate building 
fabrics (MSI = 4.26; SI\% = 85.26), and decrease structural stability and durability of building were also the top three impacts of loud music sounds on buildings sustainability performance respectively.

Generally, based on the means score index, Table 3 revealed that social sustainability performance of building with average means score index of 4.48 was mostly affected by the loud music sounds followed by the economic sustainability with MSI of 4.01, technical sustainability with MSI of 3.93, and lastly environmental sustainability with MSI of 3.80 respectively. The high average means scores for these major sustainability criteria implies that loud music sounds have high severe impact on the overall sustainability performance of buildings in Nnewi city like in other major cities in the Anambra State. This is also attested by the values of severity index percent computed across all variables.

Table 4. Analysis of the impact of loud music sounds on the sustainability performance of building (Responses from Onitsha)

\begin{tabular}{|c|c|c|c|c|c|c|c|c|c|}
\hline SN & Variable & 1 & 2 & 3 & 4 & 5 & $\begin{array}{l}\text { Mean } \\
\text { Score } \\
\text { Index }\end{array}$ & $\begin{array}{l}\text { Severity } \\
\text { Index (\%) }\end{array}$ & $\begin{array}{l}\text { Group } \\
\text { mean/ } \\
\text { Std D. }\end{array}$ \\
\hline \multicolumn{10}{|c|}{ Environmental Sustainability } \\
\hline 1 & Increase energy consumption in building & & 18 & 42 & 46 & 35 & 3.89 & 77.87 & \multirow{6}{*}{$\begin{array}{l}3.95 \\
1.07\end{array}$} \\
\hline 2 & Release volatile organic compounds (VOC) & 15 & 38 & 56 & 22 & 10 & 2.86 & 56.31 & \\
\hline 3 & Release toxic air contaminants & & & 30 & 43 & 68 & 4.27 & 85.39 & \\
\hline 4 & Decrease indoor environmental quality & & & & 28 & 113 & 4.80 & 96.03 & \\
\hline 5 & Release environmental pollution & & & 4 & 35 & 102 & 4.70 & 93.90 & \\
\hline 6 & Disrupt biodiversity and natural habitats & & 14 & 73 & 34 & 20 & 3.43 & 68.51 & \\
\hline \multicolumn{10}{|c|}{ Social Sustainability } \\
\hline 1 & Threat to security of building & 3 & 22 & 20 & 80 & 16 & 3.60 & 71.91 & \multirow{14}{*}{$\begin{array}{l}4.39 \\
0.71\end{array}$} \\
\hline 2 & $\begin{array}{l}\text { Threat to health and wellbeing of users and } \\
\text { occupants }\end{array}$ & & & & 13 & 128 & 4.91 & 98.16 & \\
\hline 3 & Increase workplace accidents and injuries & & 7 & 76 & 43 & 15 & 3.47 & 69.36 & \\
\hline 4 & Decrease users' comfort and satisfaction & & & & 25 & 116 & 4.82 & 96.45 & \\
\hline 5 & Sleep disturbance & & & 6 & 35 & 100 & 4.67 & 93.33 & \\
\hline 6 & $\begin{array}{c}\text { Create tension or anxiety within the } \\
\text { building }\end{array}$ & & & 11 & 81 & 49 & 4.27 & 85.39 & \\
\hline 7 & Psychological damage to users/occupants & & & & 56 & 85 & 4.60 & 92.06 & \\
\hline 8 & $\begin{array}{c}\text { Increase annoyance, anger and frustration in } \\
\text { users/occupants }\end{array}$ & & & 14 & 27 & 110 & 4.96 & 99.29 & \\
\hline 9 & $\begin{array}{c}\text { Increase blood pressure or stress levels in } \\
\text { users/occupants }\end{array}$ & & & 18 & 63 & 60 & 4.30 & 85.96 & \\
\hline 10 & $\begin{array}{c}\text { Increase rate of sickness or absenteeism in } \\
\text { users/occupants }\end{array}$ & & & 64 & 30 & 47 & 3.88 & 77.59 & \\
\hline 11 & $\begin{array}{c}\text { Decrease performance and productivity of } \\
\text { users/occupants }\end{array}$ & & & 24 & 43 & 74 & 4.35 & 87.09 & \\
\hline 12 & $\begin{array}{l}\text { Increase Eardrum damage or hearing } \\
\text { difficulties }\end{array}$ & & & 9 & 34 & 98 & 4.63 & 92.62 & \\
\hline 13 & Speech interference & & & 18 & 48 & 75 & 4.40 & 88.09 & \\
\hline 14 & Reduce quality of life & & & & 61 & 80 & 4.57 & 91.35 & \\
\hline \multicolumn{10}{|c|}{ Economic Sustainability } \\
\hline 1 & Decrease housing price and value & & & 4 & 55 & 82 & 4.55 & 91.06 & \multirow{4}{*}{$\begin{array}{l}4.09 \\
0.88\end{array}$} \\
\hline 2 & Increase maintenance cost of building & & 20 & 34 & 45 & 42 & 3.77 & 75.46 & \\
\hline 3 & Increase medical cost to users/occupants & & & 39 & 60 & 42 & 4.02 & 80.43 & \\
\hline 4 & Increase insurance premium & & 11 & 24 & 61 & 45 & 3.99 & 79.86 & \\
\hline \multicolumn{10}{|c|}{ Technical Sustainability } \\
\hline 1 & Deteriorate building fabrics & & 10 & 33 & 51 & 47 & 3.96 & 79.15 & \multirow{5}{*}{$\begin{array}{l}3.73 \\
0.97\end{array}$} \\
\hline 2 & $\begin{array}{l}\text { Increase sound induced Vibrations in } \\
\text { building }\end{array}$ & & & & 40 & 101 & 4.72 & 94.33 & \\
\hline 3 & $\begin{array}{l}\text { Decrease structural stability and durability } \\
\text { of building }\end{array}$ & & 21 & 68 & 37 & 15 & 3.33 & 66.52 & \\
\hline 4 & $\begin{array}{c}\text { Reduce functionality and serviceability of } \\
\text { building }\end{array}$ & & 32 & 57 & 44 & 8 & 3.20 & 63.97 & \\
\hline 5 & Induce reverberation and reflection & & 12 & 70 & 39 & 20 & 3.48 & 69.50 & \\
\hline
\end{tabular}


Table 4 showed the result of the impact of loud music sounds on the sustainability performance of building from Onitsha City. The results showed that decrease in indoor environmental quality $(\mathrm{MSI}=4.80 ; \mathrm{SI} \%=96.03)$ and release of environmental pollution $(\mathrm{MSI}=4.70$; $\mathrm{SI} \%=$ 93.90) were the top two environmental impact of loud music sounds on buildings, similar to the result in Table 3. Similarly, increase annoyance, anger and frustration in users/occupants (MSI = 4.96; SI\% = 99.29), and Threat to health and wellbeing of users and occupants (MSI = 4.91; SI\% $=98.16$ ) were the two top social impact of loud music sounds on buildings.

For economic sustainability, decrease housing price and value $(\mathrm{MSI}=4.55$; $\mathrm{SI} \%=91.06)$ and increase medical cost to users/occupants (MSI $=4.02$; $\mathrm{SI} \%=80.43$ ) were the two most severe impacts of loud music sounds on buildings. In the same vein, increase sound induced vibrations in building (MSI $=4.72 ;$ SI $\%=94.33$ ) and deteriorate building fabrics (MSI = 3.96; SI\% = 79.15) were the two most severe technical impacts of loud music sounds on buildings.

The results further showed that social sustainability performance of building was mostly affected by the loud music sounds with average means score index of 4.39, followed by the economic sustainability (4.09), environmental sustainability (3.95), and lastly technical sustainability (3.73) respectively. The high average means scores also imply that loud music sounds severely impact the overall sustainability performance of buildings in Onitsha city.

\section{Test of Hypothesis}

To further give credence to the results of this study, significance of the severity of impacts of loud music sounds on the sustainability performance of buildings were analysed. The following hypothesis is stated to give direction to the study. The results the analyses are presented in Tables 5 - 8 .

$\mathbf{H}_{\mathbf{0}}$ : There is no significance difference in the severity of the impacts of loud music sounds on the sustainability performance of buildings across the three cities of Anambra State.

The result of Table 5 showed that the value of F-ratio (2.794) is less than F-critical (3.021) and P-value (0.067) is greater than the Alpha (0.05). In this case, the null hypothesis is accepted. It then implies that there is no significance difference in the severity of impacts of loud music sounds on environmental sustainability performance of buildings across the three cities of Anambra State. This shows that loud music sounds are being perceived to have almost the same environmental impacts on buildings across the three cities of Anambra State as can be seen in the averages means scores for environmental sustainability in Tables 2, 3 and 4.

Although the results of averages mean scores in Tables 2, 3 and 4 showed that social sustainability performance of buildings was mostly affected by the impact of loud music sounds across the three cities of Anambra State with greatest values, Table 6 revealed that the value of F-ratio (4.275) is greater than F-critical (3.021) and $P$-value (0.017) is less than the Alpha (0.05). In this case, the null hypothesis is rejected and it concludes that there is significance difference in the severity of impacts of loud music sounds on social sustainability performance of buildings across the three cities of Anambra State. This scenario could be attributed to the differences in the social status of the three cities; whereas Awka is the administrative capital of Anambra State, Nnewi is an industrial city while Onitsha is a commercial city.

Table 5. ANOVA table and F - statistic for differences in the severity of impacts on environmental sustainability of buildings

\begin{tabular}{|c|c|c|c|c|c|c|c|}
\hline Sources & Sum of squares & Degree of freedom & Mean squares & F-Ratio & F-critical & $P$-value & Decision \\
\hline Between & 6.141 & 2 & 3.070 & \multirow{3}{*}{2.794} & \multirow{3}{*}{3.021} & \multirow{3}{*}{0.067} & \multirow{3}{*}{ Accept $\mathrm{H}$} \\
\hline Within & 390.153 & 355 & 1.099 & & & & \\
\hline Total & 396.294 & 357 & & & & & \\
\hline
\end{tabular}

Table 6. ANOVA table and F - statistic for differences in the severity of impacts on social sustainability of buildings

\begin{tabular}{|c|c|c|c|c|c|c|c|}
\hline Sources & Sum of squares & Degree of freedom & Mean squares & F-Ratio & F critical & P-value & Decision \\
\hline Between & 3.406 & 2 & 1.703 & \multirow{3}{*}{4.275} & \multirow{3}{*}{3.021} & \multirow{3}{*}{0.017} & \multirow{3}{*}{ Reject $\mathrm{H}_{0}$} \\
\hline Within & 141.382 & 355 & 0.398 & & & & \\
\hline Total & 144.788 & 357 & & & & & \\
\hline
\end{tabular}

Table 7. ANOVA table and F - statistic for differences in the severity of impacts on economic sustainability of buildings

\begin{tabular}{|c|c|c|c|c|c|c|c|}
\hline Sources & Sum of squares & Degree of freedom & Mean squares & F-Ratio & F critical & P-value & Decision \\
\hline Between & 2.108 & 2 & 1.054 & \multirow{3}{*}{1.252} & \multirow{3}{*}{3.021} & \multirow{3}{*}{0.296} & \multirow{3}{*}{ Accept $\mathrm{H}_{0}$} \\
\hline Within & 298.981 & 355 & 0.842 & & & & \\
\hline Total & 301.089 & 357 & & & & & \\
\hline
\end{tabular}


Table 8. ANOVA table and F - statistic for differences in the severity of impacts on technical sustainability of buildings

\begin{tabular}{|c|c|c|c|c|c|c|c|}
\hline Sources & Sum of squares & Degree of freedom & Mean squares & F-Ratio & F critical & p-value & Decision \\
\hline Between & 2.859 & 2 & 1.430 & \multirow{3}{*}{1.405} & \multirow{3}{*}{3.021} & \multirow{3}{*}{0.247} & \multirow{3}{*}{ Accept $\mathrm{H}_{0}$} \\
\hline Within & 361.538 & 355 & 1.018 & & & & \\
\hline Total & 364.397 & 357 & & & & & \\
\hline
\end{tabular}

The result of Table 7 showed that the value of F-ratio (1.252) is less than F-critical (3.021) and P-value (0.296) is greater than the Alpha (0.05). In this case, the null hypothesis is accepted and it implies that there is no significance difference in the severity of impacts of loud music sounds on economic sustainability performance of buildings across the three cities of Anambra State. It further implies that loud music sounds are being perceived to have almost the same economic impacts on buildings across the three cities of Anambra State as it can also be seen in the averages means scores for economic sustainability in Tables 2, 3 and 4.

The result of Table 8 revealed that the value of F-ratio (1.405) is less than F-critical (3.021) and P-value (0.247) is greater than the Alpha (0.05). This means that the null hypothesis is accepted. It then implies that there is no significance difference in the severity of impacts of loud music sounds on technical sustainability performance of buildings across the three cities of Anambra State. It further implies that loud music sounds are being perceived to have almost the same technical impacts on buildings across the three cities of Anambra State. This can equally be attested by the averages means score values for technical sustainability in Tables 2, 3 and 4.

From the results of this study, it was shown that the impact of loud music sound on the sustainability performance of buildings in Anambra State is obvious. The general consensus was that loud music sounds affect environmental, social, economic and technical sustainability performance buildings, but the greatest effect was found on social sustainability performance, followed by economic performance, environmental and technical respectively. However, while there was significant agreement about the severity of the impact of loud music sounds on environmental, economic and technical sustainability performance buildings; there was significant disagreement among the users/occupies of buildings in the three cities of Anambra State about the level of severity of the impact of loud music sounds on social sustainability performance buildings. This could be as a result of differences in the social status of the cities. Whereas Awka is an administrative capital of Anambra State, Nnewi is a known industrial city and Onitsha is a globally recognised commercial city.

The result of this study therefore is in line with that of Dolezal and Spitzbart-Glasl [38] who found that acoustic quality of building components can have impact on the ecological performance of the whole building and counterbalance advantages already gained in the sustainability rating. This study is also supported by Schiavi and Rossi and Jablonska et al. [65,66].

\section{Conclusions}

Although music is not as important as building in the human priority needs, it plays a crucial role in the socio-cultural life of every human being. However, when the sounds of music become loud, uncoordinated and uncontrolled they are detrimental to human lives and the building in which we live. The fact that music sounds is increasingly becoming worrisome in our today's society arouse the need for this study. Thus, this study has found that loud music sounds principally affect the sustainability performance of buildings in four different dimensions. They are environmental, social economic and technical dimensions. Among these dimensions, the study found that social sustainability performance of buildings was mostly affected. The study further established that there were high severity impacts of loud music sounds on buildings based on the four sustainability criteria across the three cities of Anambra State. However, there were significance differences in the severity of impacts of loud music sounds on social sustainability performance of buildings across the three cities of Anambra State due to differences in the social status of the cities.

Undoubtedly, this study has highlighted the need to reconsider certain aspects of building design and construction to incorporate this trend having seen the severity of the impacts of loud music sounds on buildings. The study craves for a rethink in the underlying principles behind ecomusicology and sustainable building and their interrelationships. It would therefore, awaken the conscience of the Anambra State Government towards putting in place an enabling law that would curtail the effect of this phenomenon.

On this premise, the study further hankers for change in the design and construction of buildings that will incorporate the provisions of National Building Code as regards the sound control in buildings. Technically, the general sustainability strategies for improving acoustics performance of buildings such as absorption, mechanical decoupling, mechanical damping, blocking, covering, etc., should be adopted and promotion of acoustic practices that would improve sustainable performance of our buildings and reduce the consequential effects of music sounds in buildings. Furthermore, there is need to activate and review the existing zoning laws and policies in the State, and to 
borrow a leaf from Lagos State Government in enacting a law against noise pollution. Finally, there is a need for the Anambra State Government to revisit the structural plans for the three cities prepared by the UN-HABITAT in collaboration with Anambra State Government.

\section{REFERENCES}

[1] D. Bendrups, K. Barney, C. Grant. An introduction to sustainability and ethnomusicology in the Australasian context, Musicology Australia, Vol. 35, No. 2, 153-158, 2013. https://doi.org/10.1080/08145857.2013.844470.

[2] N. S. Eidsheim. Sensing sound: Singing \& listening as vibrational practice, Duke University Press, Durham, London, 2015.

[3] M. Reybrouck, P. Podlipniak, D. Welch. Music and noise: Same or different? What our body tells us, Frontier in Psychology, 10, 1153, 2019. https://doi.org/10.3389/fpsyg. 2019.01153.

[4] S. J. Wolcott. The role of music in the transition towards a culture of sustainability, Empowering Sustainability International Journal, Vol. 3, No. 1, 1-19, 2016. Online available from https://escholarship.org/uc/item/4vx624mc.

[5] J. Hawkes. The fourth pillar of sustainability: Culture's essential role in public planning, Common Ground Publishing, Victoria, 2001.

[6] J. T. Titon. Music and sustainability: An ecological viewpoint, The World of Music, Vol. 51, No. 1, 112 -123, 2009a. Online available from http://www.jstor.org/stable/4 1699866.

[7] D. O. A. Ogunrinade. Music education as a pillar to sustainable development in Nigeria, Journal of Economics and Sustainable Development, Vol. 6, No. 3, 83-86, 2015.

[8] J. T. Titon. Economy, ecology, and music: An introduction, The World of Music, Vol. 51, No. 1, 5-15, 2009b. Online available from http://www.jstor.org/stable/41699860.

[9] A. M. Emielu. Popular music and youth empowerment in Nigeria, In I. Nwankwo, T. Utoh-Ezeajugh \& D.Dunca (eds.), Book of Proceedings, Femi Osofisan International Conference on Performance, Valid Publishing Coy, Awka, 2008.

[10] A. S. Allen. Ecomusicology: Music, culture, nature ... and change in environmental studies, Journal of Environmental Studies and Sciences, Vol. 2, No. 2, 192-201, 2012.

[11] J. L. Publicover, T. S. Wright, S. Baur, P. N. Duinker. Music as a tool for environmental education and advocacy: Artistic perspectives from musicians of the Playlist for the Planet, Environmental Education Research, Vol. 24, No. 7, 925- 936, 2018. https://doi.org/10.1080/13504622.2017.13 65356.

[12] H. Rees. Environmental crisis, culture loss, and a new musical aesthetics: China's 'original ecology folksongs' in theory and practice, Journal of the Society for Ethnomusicology, Vol. 60, No. 1, 53-88, 2016.
[13] B. M. Silver. Birdsong and a Song about a Bird: Popular Music and the Mediation of Traditional Ecological Knowledge in Northeastern Brazil, Journal of the Society for Ethnomusicology, 59(3), 380-397, 2015.

[14] O. S Titus, R. O. Titus. Jimi Solanke and Ebenezer Obey’s Music on Environmental Degradation and Flood Disaster in Ibadan, Nigeria, Polymath: An Interdisciplinary Arts and Sciences Journal, 111-130, 2017.

[15] T. Challe. Ecomusicology: back to the roots of sound/music and environmental sustainability, Master of Arts Thesis, The City University of New York, CUNY Academic Works, 2015. Online available from https://academicworks.cuny.e du/gc_etds.

[16] S. Y. Janjua, P. K. Sarker. W. K. Biswas. A review of residential buildings' sustainability performance using a life cycle assessment approach, Journal of Sustainability Research, Vol. 1, No. 1, e190006, 2019. https://doi.org/10. 20900/jsr20190006.

[17] D. Welch, G. Fremaux. Understanding why people enjoy loud sound, Seminars in Hearing, Vol. 38, No. 4, 348-358, 2017a. https://doi.org/10.1055/s-0037-1606328.

[18] D. Welch, G. Fremaux. Why do people like loud sound? A qualitative study International Journal of Environmental Research and Public Health, Vol. 14, No. 8, 908, 2017b. https://doi.org/10.3390/ijerph14080908

[19] W. Williams, E. F. Beach, M. Gilliver. Clubbing: the cumulative effect of noise exposure from attendance at dance clubs and night clubs on whole-of-life noise exposure, Noise Health, Vol. 12, No. 48, 155-158, 2010. DOI: 10.4103/1463-1741.64970.

[20] M. S. Hammer, T. K. Swinburn, R. L. Neitzel. Environmental noise pollution in the United States: Developing an effective public health response, Environmental Health Perspective, Vol. 122, No. 2, 115-119, 2014. https://doi.org/10.1289/ehp.1307272.

[21] T. O. Iyendo. Exploring the effect of sound and music on health in hospital settings: A narrative review, International Journal of Nursing Studies, Vol. 63, 82-100, 2016. https://doi.org/10.1016/j.ijnurstu.2016.08.008.

[22] A. Dobrucki, M. J. Kin, B. Kruk. Various aspects of auditory fatigue caused by listening to loud music, In: S. Hatzopoulos (ed) Advances in Clinical Audiology, IntechOpen, 2017. http://dx.doi.org/10.5772/64611.

[23] B. C. J. Moore. Effects of sound-induced hearing loss and hearing aids on the perception of music. Journal of the Audio Engineering Society, Vol. 64, No. 3, 112-123, 2016. https://doi.org/10.17743/jaes.2015.0081.

[24] N. Petrescu. Loud music listening. McGill journal of medicine, MJM: An international Forum for the Advancement of Medical Sciences by Students, Vol. 11, No. 2, 169-176, 2008.

[25] G. Marques, R. Pitarma. Indoor air quality monitoring for enhanced healthy buildings. In: M. A. Mujeebu Indoor Environmental Quality, IntechOpen, 2018. http://dx.doi.or g/10.5772/intechopen.81478.

[26] Wilson, J. (2017). The sound of sustainability: acoustics in high-performance design, The Building Green Report, Vol. 
26, No. 9, 1-19.

[27] F. Cotana, M. Goretti. Acoustic classification of buildings: impact of acoustic performances of a high energy-efficient building on quality and sustainability indicators, Proceedings of 20th International Congress on Acoustics, ICA 2010, 23-27 August, 2010, Sydney, Australia.

[28] E. Ojukwu, E. Obielozie, C. Esimone. Nigerian values and contemporary popular music: a new look, Ogirisi: A New Journal of African Studies, Vol. 12, 114-129, 2016. http://dx.doi.org/10.4314/og.v12i s1.7.

[29] J. T. Titon. The Nature of Ecomusicology, Música e Cultura: revista da ABET, Vol. 8, No. 1, 8-18, 2013.

[30] W. Brodsky, Z. Slor. Background music as a risk factor for distraction among young-novice drivers, Accident Analysis \& Prevention, Vol. 59, 382-393, 2013. https://doi.org/10.1 016/j.aap.2013.06.022.

[31] B. H. Dalton, D. G. Behm. Effects of noise and music on human and task performance: A systematic review, Occupational Ergonomics, Vol. 7, 143-152, 2007.

[32] B. Millet, S. Ahn, J. Chattah. The impact of music on vehicular performance: A meta-analysis, Transportation Research Part F: Traffic Psychology and Behaviour, Vol. 60, 743-760, 2019. https://doi.org/10.1016/j.trf.2018.10.007.

[33] A. B. Ünal, L. Steg, K. Epstude. The influence of music on mental effort and driving performance, Accident Analysis \& Prevention, Vol. 48, 271-278, 2012. https://doi.org/10.1 016/j.aap.2012.01.022.

[34] M. Hodgson. Acoustical evaluation of six 'green' office buildings, Journal of Green Building, Vol. 3, No. 4, 108-118, 2006.

[35] J. Nurzyński. Sustainability and protection against noise in a building and its surroundings, The 2005 World Sustainable Building Conference, Tokyo, 27-29 September 2005 (SB05Tokyo), 1553-1560, 2995.

[36] N. A. A. Jalil, N. B. C. Din, N. I. M. K. Daud. A literature analysis on acoustical environment in green building design strategies, Applied Mechanics and Materials, Vol. 471, 138-142, 2013. https://doi.org/10.4028/www.scientific.net /amm.471.138.

[37] L. Zhisheng, L. Dongmei, M. Sheng, Z. Guoqiang, L. Jianlong. Noise impact and improvement on indoors acoustic comfort for the building adjacent to heavy traffic road, Chinese Journal of Population Resources and Environment, Vol. 5, No. 1, 17-25, 2007.https://doi.org/10 $.1080 / 10042857.2007 .10677482$.

[38] F. Dolezal, C. Spitzbart-Glasl. Relevance of acoustic performance in green building labels and social sustainability ratings, Energy Procedia, Vol. 78, 1629 1634, 2015. https://doi.org/10.1016/j.egypro.2015.11.241.

[39] L. T. Silva. Environmental quality health index for cities, Habitat International, Vol. 45, No. 1, 29-35, 2015. https://doi.org/10.1016/j.habitatint.2014.06.020.

[40] J. Treasure. Building in sound, BIAMP Systems Whitepaper, 2012. Online available from http://67aa6fee3b112cf7b085a 4daa72d047cd5cf1107a27466ad39b3.r75.cf1.rackcdn.com/ Biamp_Whitepaper_Building_in_Sound.pdf.
[41] E. N. Oyati, A. O. Stephen. Assessment of environmental effects of noise pollution in Auchi, Nigeria, Applied Science Reports, Vol. 18, No. 3, 100-104, 2017.

[42] S. A. Ganiyu, Y. M. D. Adedeji. A study of the sources of noise pollution and their impacts on the built environment (A case study of Oba-Ile Housing Estate, Akure, Nigeria), In S. Laryea, R. Leiringer, \& W. Hughes, (eds) Proceedings of the West Africa Built Environment Research (WABER) Conference 2011 Accra, Ghana, 19-21 July, 2011, 59-68.

[43] E. Murphy, E. A. King. Environmental Noise Pollution: Noise Mapping, Public Health, and Policy, Elsevier, Amsterdam, 2014. https://doi.org/10.1016/B978-0-12-411 595-8.00003-3

[44] F. Aletta, F. Lepore, E. Kostara-Konstantinou, J. Kang, A. Astolfi. An experimental study on the influence of soundscapes on people's behaviour in an open public space, Applied Sciences, Vol. 6, No. 10, 276, 2016. https://doi.or g/10.3390/app6100276.

[45] M. Fran`ek, L. van Noorden, L. Režný. Tempo and walking speed with music in the urban context, Frontiers in Psychology, Vol. 5, 1361, 2014. https://doi.org/10.3389/fp syg.2014.01361.

[46] Q. Meng, J. Kang. Influence of social and behavioural characteristics of users on their evaluation of subjective loudness and acoustic comfort in shopping malls, PLoS One, Vol. 8, No. 1, e54497, 2013. https://doi.org/10.1371/journa l.pone.0054497.

[47] H. M. E. Miedema. Relationship between exposure to multiple noise sources and noise annoyance. Journal of the Acoustical Society of America, Vol. 116, No. 2, 949-957, 2004. https://doi.org/10.1121/1.1766305.

[48] X. Ren, J. Kang. Interactions between landscape elements and tranquillity evaluation based on eye tracking experiments, Journal of the Acoustical Society of America, Vol. 138, No. 5, 3019-3022, 2015. https://doi.org/10.1121/ 1.4934955 .

[49] Q. Meng, T. Zhao, J. Kang. Influence of music on the behaviors of crowd in urban open public spaces, Frontiers in Psychology, Vol. 9, 596, 2018. https://doi.org/10.3389/f psyg.2018.00596.

[50] M. Basner, W. Babisch, A. Davis, M. Brink, C. Clark, S. Janssen, et al. Auditory and non-auditory effects of noise on health. Lancet, Vol. 383, No. 9925, 1325-1332, 2014. https://doi.org/10.1016/S0140-6736(13)61613-X.

[51] J. A Alves, L. T. Silva, P. C. C. Remoaldo. The influence of low-frequency noise pollution on the quality of life and place in sustainable cities: a case study from Northern Portugal, Sustainability, Vol. 7, No. 10, 13920-13946, 2015. https://doi.org/10.3390/su71013920.

[52] O. Berger-Tal, B. B. M. Wong, U. Candolin, J. Barber. What evidence exists on the effects of anthropogenic noise on acoustic communication in animals? A systematic map protocol, Environmental Evidence, Vol. 8, No. 18, 2019. https://doi.org/10.1186/s13750-019-0165-3.

[53] R. Sordello, F. Flamerie De Lachapelle, B. Livoreil, S. Vanpeene. Evidence of the environmental impact of noise pollution on biodiversity: a systematic map protocol, Environmental Evidence, Vol. 8, No. 8, 2019.https://doi.or 


\section{g/10.1186/s13750-019-0146-6.}

[54] J. Martí. When music becomes noise: Sound and music that people in Barcelona hear but don't want to listen to, The World of Music, Vol. 39, No. 2, 9-17, 1997.

[55] E. Ottoz, L. Rizzi, F. Nastasi. Recreational noise: Impact and costs for annoyed residents in Milan and Turin, Applied Acoustics, Vol. 133, 173-181, 2018. https://doi.org/10.101 6/j.apacoust.2017.12.021.

[56] G. C. Emenike, A. P. Sampson. Noise levels and quality of livelihoods in residential neighbourhoods of Port Harcourt Metropolis, Nigeria, European Journal of Earth and Environment, Vol. 4, No. 1, 19-28, 2017.

[57] J. Nyoni. The effects of noise and excessive sound pressure levels (SPLs) on office occupants and the strategy to improve acoustic comfort in office buildings, Master of Facilities Management Thesis, Faculty of Science, Engineering and Built environment, School of Architecture and Built Environment, Deakin University, Australia, 2015. DOI: 10.13140/RG.2.1.2516.9527.

[58] Association of Australian Acoustical Consultants. Guideline for child care centre acoustic assessment, 2013. Online available from www.aaac.org.au.

[59] M. A. Mujeebu. Introductory chapter: Indoor environmental quality, In: M.A. Mujeebu Indoor Environmental Quality, IntechOpen, 2019. http://dx.doi.org/10.5772/intechopen.83 612.

[60] C. E. Ng. Effects of building construction noise on residents: A quasi-experiment, Journal of Environmental Psychology, Vol. 20, No. 4, 375-385, 2000. https://doi.org/10.1006/jevp .2000 .0177 .

[61] E. O. Oloruntoba, R. A. Ademola, M. K. C. Sridhar, S. A. Agbola, F. O. Omokhodion, G. R. E. E. Ana, R. T. Alabi. Urban Environmental Noise Pollution and Perceived Health Effects in Ibadan, Nigeria, African Journal of Biomedical Research, Vol. 15, No. 2, 77-84, 2012.

[62] The Department of Health. The health effects of environmental noise, Department of Health, Commonwealth of Australia, Canberra, Australia, 2018. Online available fromhttps://www1.health.gov.au/internet/ main/publishing.nsf/Content/A12B57E41EC9F326CA257 BF0001F9E7D/\$File/health-effects-Environmental-Noise2018.pdf.

[63] World Health Organisation. Burden of disease from environmental noise: Quantification of healthy life years lost in Europe, The WHO European Centre for Environment and Health, WHO Regional Office for Europe, Bonn Office, Copenhagen, 2011. Online available from htt p://www.euro.who.int/_data/assets/pdf_file/0008/136466/ e94888.pdf.

[64] World Health Organisation. Environmental noise guidelines for the European region, WHO Regional Office for Europe, Copenhagen, Denmark, 2018. Online available from https://apps.who.int/iris/handle/10665/279952.

[65] A. Schiavi, L. Rossi. Vibration perception in buildings: A survey from the historical origins to the present day, Energy Procedia, Vol. 78, 2-7, 2015.https://doi.org/10.1016/j.egyp ro.2015.11.094.
[66] J. Jablonska, E. Trocka-Leszczynska, R. Tarczewski. Sound and architecture - Mutual influence, Energy Procedia, Vol. 78, 31-36, 2015. https://doi.org/10.1016/j.egypro.2015.11. 110.

[67] S. H. Park, P. J. Lee, B. K. Lee. Levels and sources of neighbour noise in heavyweight residential buildings in Korea, Applied Acoustics, Vol. 120, 148-157, 2017. https://doi.org/10.1016/j.apacoust.2017.01.012

[68] A. Zalejska-Jonsson. Perceived acoustic quality and effect on occupants' satisfaction in green and conventional residential buildings, Buildings, Vol. 9, No. 1, 24, 2019. https://doi.org/10.3390/buildings9010024

[69] National Population Commission (NPC). 2006 Population and Housing Census of the Federal Republic of Nigeria, National and State Population and Housing Tables, Priority Tables, Vol. I, 2009. Online available fromwww.populatio n.gov.ng.

[70] UN-Habitat. Structure Plan for Awka and Satellite Towns, United Nations Human Settlements Programme, Nairobi, Kenya, 2009a. Online available from http://www.unhabitat .org.

[71] UN-Habitat. Structure Plan for Nnewi and Satellite Towns, United Nations Human Settlements Programme, Nairobi, Kenya, 2009b. Online available from http://www.unhabitat .org.

[72] UN-Habitat. Structure Plan for Onitsha and Satellite Towns, United Nations Human Settlements Programme, Nairobi, Kenya, 2009c. Online available from http://www.unhabitat .org.

[73] Anambra State Bureau of Statistics. 2011 Statistical Year Book, Ministry of Economic planning and Budget, Awka, 2012. Online available from https://www.nigerianstat.gov. ng > pdfuploads > Statistical Year Book 2009

[74] G. D. Israel. Determining sample size, Agricultural Education and Communication Department, UF/IFAS Extension, University of Florida, PEOD6, Reviewed version, 2013. Online available from http://edis.ifas.ufl.edu.

[75] W. G. Cochran. Sampling techniques, 3rd Ed., John Wiley \& Sons Inc. New York, 1977.

[76] Data Star. What every researcher should know about statistical significance, 2008. Online available from https://www.surveystar.com/startips.

[77] J. E. Bartlett, J. W. Kotrlik, C. C. Higgins. Organisational research: Determining appropriate sample size in survey research, Learning and Performance Journal, Vol. 19, No. 1, 43-50, 2001. 